\title{
Proteomic analysis of acidic chaperones, and stress proteins in extreme halophile Halobacterium NRC-I : a comparative proteomic approach to study heat shock response Hem D Shukla*
}

Address: Center of Marine Biotechnology, University of Maryland Biotechnology Institute, Baltimore, MD 21202, USA

Email: Hem D Shukla* - shukla@umbi.umd.edu

* Corresponding author

Published: 19 April 2006

Proteome Science 2006, 4:6 doi:10.1186/1477-5956-4-6

This article is available from: http://www.proteomesci.com/content/4/1/6

(C) 2006 Shukla; licensee BioMed Central Ltd.

This is an Open Access article distributed under the terms of the Creative Commons Attribution License (http://creativecommons.org/licenses/by/2.0), which permits unrestricted use, distribution, and reproduction in any medium, provided the original work is properly cited.

\begin{abstract}
Background: Halobacterium sp. NRC-I is an extremely halophilic archaeon and has adapted to optimal growth under conditions of extremely high salinity. Its proteome is highly acidic with a median pl of 4.9, a unique characteristic which helps the organism to adapt high saline environment. In the natural growth environment, Halobacterium NRC-I encounters a number of stressful conditions including high temperature and intense solar radiation, oxidative and cold stress. Heat shock proteins and chaperones play indispensable roles in an organism's survival under many stress conditions. The aim of this study was to develop an improved method of 2-D gel electrophoresis with enhanced resolution of the acidic proteome, and to identify proteins with diverse cellular functions using in-gel digestion and LC-MS/MS and MALDI-TOF approach.
\end{abstract}

Results: A modified 2-D gel electrophoretic procedure, employing IPG strips in the range of $\mathrm{pH} 3-6$, enabled improved separation of acidic proteins relative to previous techniques. Combining experimental data from 2-D gel electrophoresis with available genomic information, allowed the identification of at least 30 cellular proteins involved in many cellular functions: stress response and protein folding (CctB, PpiA, DpsA, and MsrA), DNA replication and repair (DNA polymerase $A \alpha$ subunit, Orc4/CDC6, and $U v \operatorname{rr}$ ), transcriptional regulation (Trh5 and ElfA), translation (ribosomal proteins Rps27ae and Rphs 6 of the $30 \mathrm{~S}$ ribosomal subunit; Rpl3 I eand Rpl/8e of the $50 \mathrm{~S}$ ribosomal subunit), transport (YufN), chemotaxis (CheC2), and housekeeping (ThiC, ThiD, FumC, ImD2, GapB, TpiA, and PurE). In addition, four gene products with undetermined function were also identified: Vngl807H, Vng0683C, Vngl300H, and Vng6254. To study the heat shock response of Halobacterium NRC-I, growth conditions for heat shock were determined and the proteomic profiles under normal $\left(42^{\circ} \mathrm{C}\right)$, and heat shock $\left(49^{\circ} \mathrm{C}\right)$ conditions, were compared. Using a differential proteomic approach in combination with available genomic information, bioinformatic analysis revealed five putative heat shock proteins that were upregulated in cells subjected to heat stress at $49^{\circ} \mathrm{C}$, namely Dnaj, GrpE, sHsp-I, Hsp-5 and sHsp-2.

Conclusion: The modified 2-D gel electrophoresis markedly enhanced the resolution of the extremely acidic proteome of Halobacterium NRC-I. Constitutive expression of stress proteins and chaperones help the organism to adapt and survive under extreme salinity and other stress conditions. The upregulated expression pattern of putative chaperones DnaJ, GrpE, sHsp-I, Hsp-5 and sHsp-2 under elevated temperature clearly suggests that Halobacterium NRC-I has a sophisticated defense mechanism to survive in extreme environments. 


\section{Background}

Halobacterium sp. NRC-1 inhabits an extreme and dynamic environment which presents a significant challenge to its survival. The organism has the capability to adapt to $4.5 \mathrm{M}$ of salt and exhibit growth up to about $50^{\circ} \mathrm{C}$, albeit at reduced rate. It responds to a wide range of environmental perturbations including intense solar radiation, high temperature, cold, high salinity and oxidative stress [1-3]. The cells can grow using both aerobic and anaerobic respiration and have anaerobic fermentation and phototrophic capabilities [4]. The organism is genetically tractable with a wide variety of genetic tools, including cloning vectors, selectable markers, and a facile gene knockout system [5]. These facts, together with the availability of its complete genome sequence [4], make Halobacterium sp. NRC-1 an ideal system for studying responses to environmental perturbations.

The genome sequences of Halobacterium sp. NRC-1 have shown the presence of three replicons: a $2 \mathrm{Mbp}$ chromosome, and two minichromosomes of $365 \mathrm{kbp}$ (pNRC200), and $191 \mathrm{kbp}$ (pNRC100), encoding 2630 predicted proteins [4]. Bioinformatic analyses of the NRC1 genome have shown the predicted proteome to be extremely acidic, with a median pI of only 4.9 [2]. Preliminary experimental proteomic analysis of Halobacterium NRC- 1 and related halophiles has exhibited the feasibility of both two-dimensional gel electrophoretic (2-DE) analysis [6,7], liquid chromatography coupled tandem mass spectrometry (LC-MS/MS), and MALDI-TOF analysis $[7,8]$. Furthermore, mass spectrometric analysis of purple membrane preparations from Halobacterium has also been reported [9]. However, these studies have not extensively analyzed the changes in abundance of individual proteins or patterns under differential growth conditions.

Despite the recent advances in proteomic research, and improved 2-DE systems, the analysis of the Halobacterium NRC-1 proteome is a considerable challenge [7]. Because of its extreme acidity, and relatively high hydrophobicity, proteins tend to precipitate at their isoelectric point during IEF analysis $[10,11]$. Moreover, presence of salt in the sample and excess DTT at acidic $\mathrm{pH}$ leads to streaking and skewed results. These problems have previously been approached using low molecular weight cut-off columns, ultrazoom immobilized $\mathrm{pH}$ gradient strips, and combinations of IPGphor/Multiphor systems [7,12]. However, streaking at the high molecular weight region of the 2-D gels still poses considerable challenge in obtaining reproducible results, which are essential for comparative study and global protein analysis in extreme halophiles.

Heat shock response is an important homeostatic mechanism that enables cells to survive a variety of environmental stresses [13]. Some heat shock proteins are constitutively expressed in extremophiles under normal growth conditions, suggesting that they have evolved spontaneous adaptation to extreme environmental conditions [14]. These heat shock proteins function in multiprotein complexes as molecular chaperones and assist in the proper protein folding of stress damaged proteins, and stabilization of other cellular proteins [15-18].

Halobacterium NRC-1 is challenged by hostile conditions in its natural environment including intense solar radiation, high temperature, high salinity and oxidative stress. The complete genome sequence of Halobacterium NRC-1 has revealed the presence of 13 heat shock genes which belong to five major families of Hsps including alpha and beta thermosomes, DnaK, DnaJ, GrpE, DpsA, MsrA and sHsps [4]. Among them, Halobacterium NRC-1 genome contains 3 copies of small heat shock proteins (sHsps) whereas, other archaeal genomes contain only one or two copies each. Small heat shock proteins are less than 25 $\mathrm{kDa}$ in size and ubiquitous in all types of organisms, including archaea, bacteria, and eukarya [19].

In present study, a modified 2-DE procedure is employed to improve resolution of acidic proteins. Using the modified procedure, 30 abundantly expressed proteins were identified following LC-MS/MS and MALDI-TOF analyses. Further, by employing a differential protein expression analyses approach, combined with bioinformatics analyses, an attempt has been made to identify putative heat shock proteins and chaperones up regulated during temperature stress in this model extremophile.

\section{Result and discussion Optimization of 2-D gel electrophoresis for resolution of acidic proteins}

Halobacterial proteins are extremely acidic and have highly negatively charged surfaces, which are thought to enhance solubility and maintain function at high salinity [20]. In order to improve resolution and minimize streaking of proteins in the acidic range, three modifications were introduced to a recently published procedure [7]: (1), the sample was extensively dialyzed using $3 \mathrm{kDa}$ cutoff dialysis bag with at least 4 buffer changes; (2), $2.0 \%$ Tween-20, a non-ionic detergent, was used in the rehydration buffer in place of NP-40; and (3), the rehydration step was carried out at 50 volts for $16 \mathrm{hrs}$ at $22^{\circ} \mathrm{C}$. Apparently, extended rehydration of IPGready strips at low voltage prevented the usual precipitation observed at acidic $\mathrm{pH}$. These modifications effectively removed the salt and concomitantly allowed the acidic proteins to focus more efficiently at the acidic range of the IPG strip. As shown in Fig. 1, proteins were well resolved in the acidic range and very limited streaking was observed at higher MW range, unlike earlier reports $[6,7,21,22]$. However, acidic proteins which were resolved through unmodified 2-D gel 


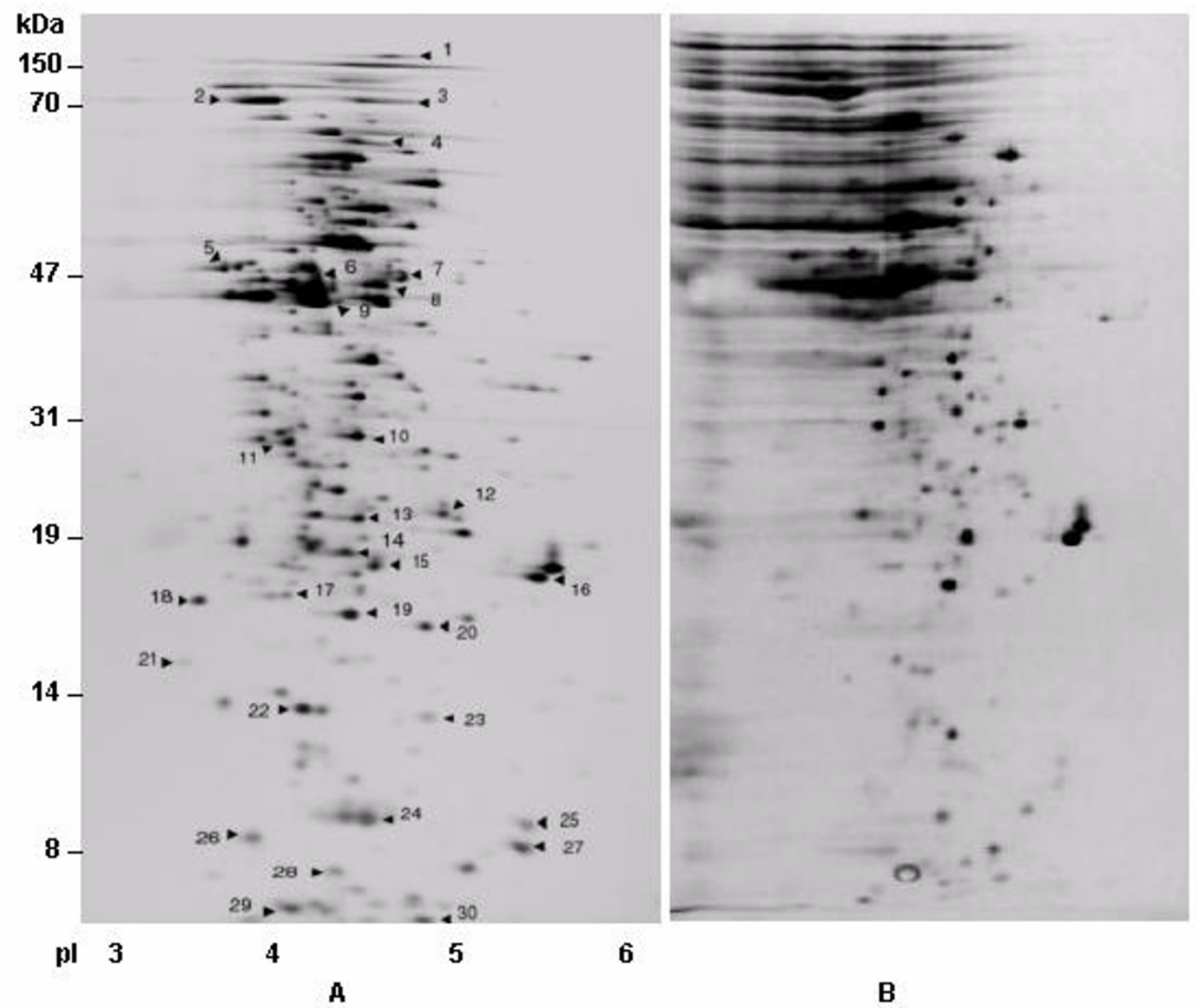

\section{Figure I}

A. Typical image of 2-D gel electrophoresis analysis of intracellular proteins of Halobacterium NRC-I (pl 3-6) by modified procedure, cells were grown under normal growth conditions. B. 2-D gel analysis of intracellular acidic proteins of Halobacterium NRC-I by unmodified procedure.

procedure resulted in horizontal and vertical streaking at higher MW range. (Fig. 1B).

By employing the modified protocol for analytical 2-DE of acidic proteins, thirty abundantly expressed proteins were identified under standard laboratory growth conditions at $42^{\circ} \mathrm{C}$ [5]. The data presented in Fig. 1 represent the reference map, which was generated using IPG ready strips of the $\mathrm{pH}$ range 3-6. In the present approach, a high degree of reproducibility was observed between gels, and replicate gel images were averaged and analyzed. Analyses of resulting gels were performed using ImageMaster software and approximately 411 protein spots were detected in the range of $10-150 \mathrm{kDa}$ with $\mathrm{pI}$ 's in the range of 3 to
6 . The average $\mathrm{pI}$ of the expressed proteome was found to be 4.42 , which is in close agreement with the predicted proteome derived from genome sequence [4]. Multiple experiments revealed that using the Image Master 2-D Software, highly reproducible data were obtained which was corroborated by earlier reports [23]. In present study, experimental pI and molecular weights were closely matched with the predicted values obtained from genome sequence. In additional experiments, few if any proteins in the neutral and basic range could be identified (data not shown), although 390 polypeptides are predicted in the Halobacterium NRC-1 genome sequence in the pI range of 7-11, similar problems were also encountered in earlier reports [24-26]. 

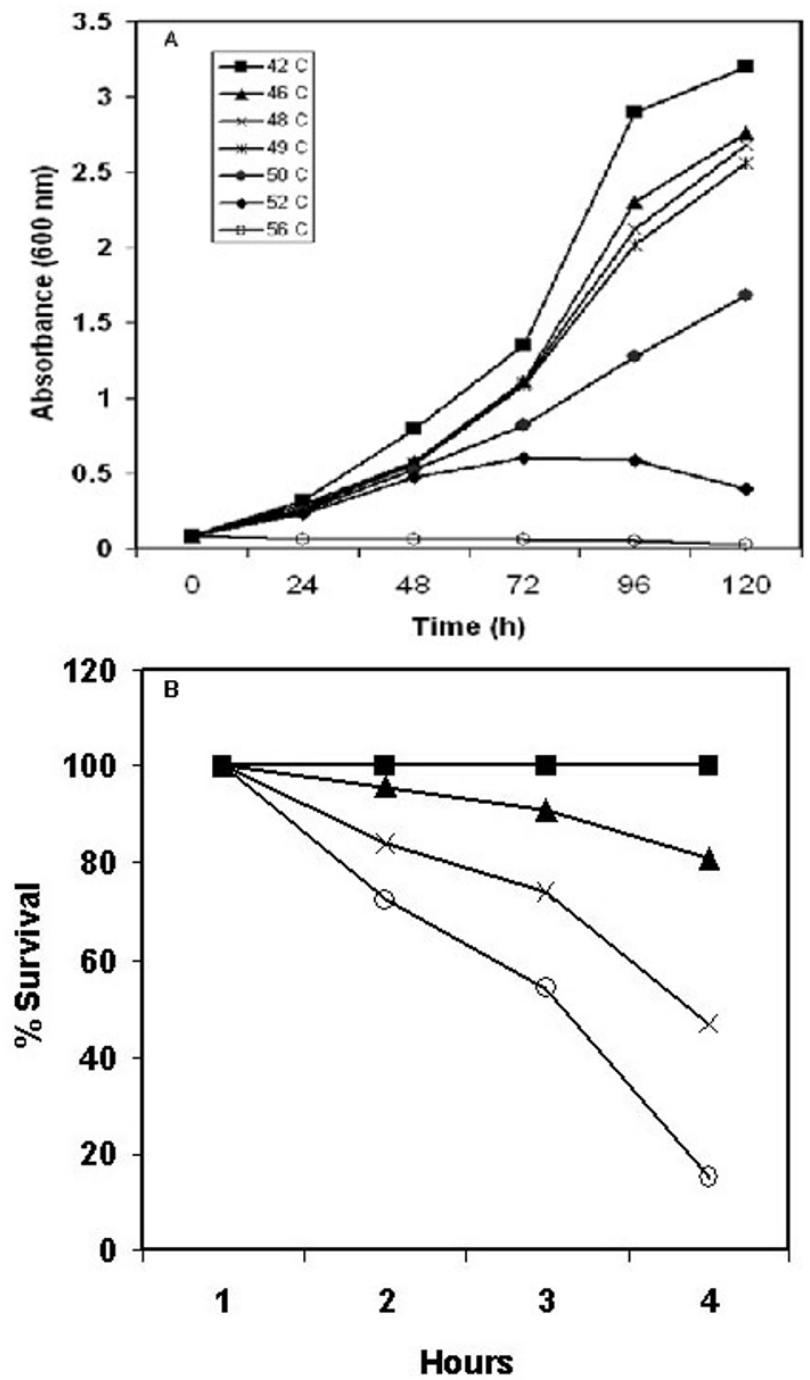

\section{Figure 2}

A. Growth curves of Halobacterium NRC-I at elevated temperatures 42 (squares), 46 (triangles), 48 (cross), 49 (asterisks), 50 (dark circles), 52 (diamonds), and $56^{\circ} \mathrm{C}$. (open circles). B. Survival of Halobacterium NRC-I at sublethal (49 ${ }^{\circ} \mathrm{C}$ - triangles), Pretreatment of cells at $49^{\circ} \mathrm{C}$ for I hour, then shifted at $56{ }^{\circ} \mathrm{C}$ (cross), and directly at lethal $\left(56^{\circ} \mathrm{C}\right.$ - open circles) temperature. Control was grown at $42{ }^{\circ} \mathrm{C}$ (dark squares).

Identification and analysis of cellular chaperones, and abundantly expressed gene products under 4.5 M of salt Based on the protein profiles of 411 acidic proteins in reference 2-D maps, 30 abundantly expressed proteins representing a wide range of $\mathrm{pI}$ and $\mathrm{MW}$ were selected for identification. Spots were excised, digested with trypsin, and the resulting peptides were analyzed by MALDI-TOF and LC-MS/MS analysis. The results presented in Fig. 1 and Table 1 show that the abundantly expressed proteins that could be identified are involved in a wide range of cellular processes. In this novel approach the peptide masses obtained from MALDI-TOF were searched against MASCOT database and top hits were precisely matched with the pI and molecular weights of predicted proteins from genome sequence, and data obtained from 2-D gel electrophoretic analyses. Thus, only closely matched values were taken into consideration for identification of proteins. Interestingly, this approach could easily identify false positive despite the fact that the MASCOT scores of some false positives were found to be higher than the actual protein identified. However, the above stated approach discounted the probability of identifying false positives and allowed us to identify the actual candidates. Similarly, the MS/MS spectra were searched against NCBInr database using SEQUEST as described in materials and methods. Proteins identified by LC-MS/MS and MALDI-TOF analysis, with experimental and theoretical $\left(\mathrm{M}_{\mathrm{r}}\right.$ and $\left.\mathrm{pI}\right)$ values are presented in Table 1 with the ORF number, protein name, MS score and percent coverage. The bioinformatics analysis of identified proteins has shown that their pI and molecular weights match with the predicted values from genome sequence [4].

\section{Protein folding and stress responses}

CctB is a beta subunit of the thermosome, which belongs to group two chaperonins in archaea and is involved in various cellular functions during stress [27]. It has been reported to suppress aggregation of normal proteins under high salt [28]. It has been observed that under temperature stress, the thermosome spontaneously assembles into filaments, which suggested that they may play a structural role in vivo [29]. In addition, other functions have been suggested for group II chaperonins which help to adapt stressful conditions, including membrane stabilization [29]. The other chaperone identified under normal growth conditions was peptidyl-prolyl isomerase or rotamase (PpiA), which facilitates proper protein folding by increasing the rate of transition of proline residues between the cis and trans states [30]. The present approach also helped identify MsrA, a stress protein involved in cellular protection from oxidative stress damage [31]. MsrA has been reported to act against oxidative damage by inactivating oxygen radicals which have the tendency to damage DNA [32]. DpsA, another protein involved in protection of DNA damage from oxidative stress, [33], could also be identified. However, recent reports suggest that DpsA protects cells against multiple stresses during stationary phase [34]. The data obtained by combination of 2-D gel, LC-MS/MS and MALDI-TOF clearly indicate that that some of the chaperones and stress proteins are constitutively expressed in the cell. This might be due to the fact that Halobacterium NRC-1 inhabits an extreme environment of high salinity and other stresses [19] and, therefore, has evolved a unique and novel strategy for 
impromptu adaptation to extreme salinity and other stresses.

\section{DNA replication, transcription, translation and repair}

The survival of Halobacterium NRC-1 under extreme environmental conditions always depends upon the successful repair and replication of genetic material. The proteomic analysis has shown the presence of polymerase A ( $\alpha$ subunit) involved in DNA replication, and Orc4/ CDC6 which plays an indispensable role in initiation of replication by binding to origin of replication. Findings also suggest that CDC6, which has AAA domain structure, is involved in the refolding of the denatured protein, protein turnover, and posttranslational modification under extreme salinity [35]. The identification of excision nuclease chain $\mathrm{C}$ (UvrC), a member of both UvrABC system and orthologous family COG0322, indicate that growing cells are exposed to high solar and UV radiation, and its expression successfully repairs the cellular DNA damage [36]. The presence of transcription regulation (Trh5, ElfA), translation [two 30S (Rps27ae, Rphs6), two $50 \mathrm{~S}$ (Rpl31e, Rpl18e) ribosomal proteins] gene products indicate that despite extreme stress conditions cell successfully maintain and regulate genetic information to its successful survival.

\section{Identification of transport, chemotaxis, and housekeeping gene products}

The proteomic analysis has also shown the presence of YufN protein which is a member of the ABC transporter family embedded in halobacterial membranes containing the pfam 02608 domain. YufN is involved in the import of nutrients into cells or the release of toxic products into the surrounding medium and functions at the expense of ATP hydrolysis [37]. This class of proteins is the most important family of membrane transporters in Halobacterium NRC-1 genome.

CheC2 is a chemotaxis protein which is a member of COG1776 family, and part of two component chemotaxis and phototaxis network module in Halobacterium NRC-1. It is envisaged that during phototaxis, this protein receives signals from photo transducers HtrI and HtrII and control a flagellar switch [38] enabling the cell to move towards ideal illumination conditions where the light driven proton pump of bacteriorhodopsin converts light energy into chemical energy [39]. The other gene products identified by proteomic analysis were ThiC, ThiD, FumC, ImD2, GapB, TpiA, and PurE, which belong to a category of proteins involved in general metabolic function [40]. In addition, four unannotated gene products of undetermined function were also identified: Vng1807H, Vng0683C, Vng1300H, and Vng6254.

\section{Survival of Halobacterium NRC-I under heat stress}

In order to examine heat shock response in Halobacterium NRC-1, differential proteomic strategy was employed; first the conditions for heat shock response were optimized and growth of Halobacterium NRC- 1 was tested at a wide range of temperatures from optimal $\left(42^{\circ} \mathrm{C}\right)$ to lethal $\left(56^{\circ} \mathrm{C}\right)$. The data presented in Fig. $2 \mathrm{~A}$, show that cells exhibited normal growth up to $49^{\circ} \mathrm{C}$, albeit with slower growth rates as compared to the control $\left(42^{\circ} \mathrm{C}\right)$. At higher temperatures $\left(>50^{\circ} \mathrm{C}\right)$ growth was inhibited and cells appeared white from photobleaching. However, viability at these higher temperatures was largely maintained for several hours and growth resumed after shifting back to $42^{\circ} \mathrm{C}$. To further assess the physiological significance of the sublethal but growth inhibitory temperature, we measured survival of Halobacterium NRC-1, after pretreatment of cells at sublethal temperature at $49^{\circ} \mathrm{C}$ for $1 \mathrm{~h}$ followed by shifting to a lethal $56^{\circ} \mathrm{C}$ for up to 6 hours and plating on $\mathrm{CM}^{+}$plates. A 2.5 -fold increase in survival was observed for cells pretreated at $49^{\circ} \mathrm{C}$ compared to cells that were directly shifted to $56^{\circ} \mathrm{C}$ (Fig 2B). For the first time it is demonstrated that when growing Halobacterium NRC-1 cells are briefly exposed to sublethal temperature they can survive a much more severe temperatures by developing thermotolerance, which is likely to be of ecophysiological relevance to the organism [41]. It seems likely that the increased thermotolerance in heat-shocked cells is ubiquitous in archaea and represents a possible mechanism for survival under thermal stress by induced synthesis of heat shock proteins [42]. As such, a classic heat shock response is observed in Halobacterium NRC-1, not surprising since this is a common stress response mechanism adapted and evolved by halophiles inhabiting hypersaline environments.

High resolution 2-D PAGE in combination with advanced ImageMaster aided analyses is a powerful tool to study microbial physiology in general. To study the induction and expression of heat shock proteins in Halobacterium NRC-1, by employing a differential proteomics approach, exponentially growing cells were subjected to heat shock conditions at $49^{\circ} \mathrm{C}$ for $8 \mathrm{hrs}$ (generation time of $\sim 6 \mathrm{hrs}$ ). Samples containing total cellular proteins were prepared from control and heat shocked cells (equal amounts) and resolved through $2-\mathrm{D}$ gels in triplicate. The gels were digitally imaged after silver staining. The data analyses showed that at least 123 proteins displayed changes in expression when the cells were shifted to elevated temperature. Consequentely, adaptation to high temperature requires substantial change in cellular protein composition [43]. Through an ImageMaster aided comparison of representative sets of gels, we observed that 63 proteins were over expressed under heat shock conditions. At least 37 proteins exhibited a greater than 2-fold increase at $49^{\circ} \mathrm{C}$. Conversely in heat shocked cells, the synthesis of 


\begin{tabular}{|c|c|c|c|c|c|c|c|c|}
\hline No. & ORF No. & Protein Name & $\begin{array}{l}\text { MS/MASCOT } \\
\text { Score }\end{array}$ & Mowse Score & \% Coverage & Annotation & Putative $\mathrm{kDa} / \mathrm{pl}$ & $\begin{array}{l}\text { Calculated } \mathrm{kDa} / \\
\mathrm{pl}\end{array}$ \\
\hline I & 2338 & polA2* & 15 & 39 & 13 & DNA polymerase & $150 / 4.38$ & $148.9 / 4.39$ \\
\hline 2 & 2096 & $\operatorname{cct} B$ & 668 & & 33 & Thermosome $\beta$ & $70 / 4.12$ & $69 / 4.1$ \\
\hline 3 & 2381 & uvrC* & 40 & 51 & 18 & Excision nuclease chain $C$ & $63.7 / 4.8$ & $63 / 4.89$ \\
\hline 4 & 6363 & Orc4/CDC6 & 82 & & 30 & Orc4/CDC6 & $58 / 4.51$ & $58 / 4.52$ \\
\hline 5 & 715 & thiC & 57 & & 28 & Thiamine biosynthesis protein & $51 / 4.15$ & $51.5 / 4.15$ \\
\hline 6 & 1601 & $g c v P 2 *$ & 20 & 47 & 20 & Glycine Dehydrogenase II & $50 / 4.43$ & $51 / 4.4$ \\
\hline 7 & 1356 & fumC & 378 & & 27 & Fumarate hydratase & $50 / 4.4$ & $50 / 4.38$ \\
\hline 8 & 2649 & eefIA & 158 & & 18 & $\begin{array}{l}\text { Translation elongation factor } \alpha \\
\text { subunit }\end{array}$ & $46 / 4.32$ & $46.2 / 4.3$ \\
\hline 9 & 2606 & thiD & 83 & & 21 & Thiamine biosynthesis protein & $45 / 4.2$ & $47 / 4.17$ \\
\hline 10 & 95 & $\operatorname{gap} B$ & 220 & & 13 & Glyceraldehyde 3-PDH & $35 / 4.26$ & $35.5 / 4.2$ \\
\hline II & 903 & yufN* & 20 & 47 & 8 & $A B C$ transporter & $33 / 4.02$ & $33.2 / 4.02$ \\
\hline 12 & 683 & vng0683C* & 73 & 63 & 14 & Hypothetical & $28 / 4.69$ & $28.9 / 4.6$ \\
\hline 13 & 2331 & vng0309C* & 56 & 46 & 12 & Hypothetical & $25 / 4.48$ & $26.9 / 4.31$ \\
\hline 14 & 1027 & tpiA & 50 & & 13 & Triosephosphate isomerase & $21 / 3.97$ & $21.3 / 4.01$ \\
\hline 15 & 2443 & $d p s A$ & 60 & & 19 & $\begin{array}{l}\text { Stress induced DNA binding } \\
\text { protein }\end{array}$ & $20 / 4.14$ & $20.4 / 4.16$ \\
\hline 16 & 890 & imD2 & 196 & & 25 & $\begin{array}{l}\text { Inosine-5'-monophosphate } \\
\text { dehydrogenase }\end{array}$ & $20 / 4.76$ & $20.1 / 4.8$ \\
\hline 17 & 1914 & ppiA* & 20 & 45 & 11 & Peptidyl proryl isomerase & $20 / 4.02$ & $21 / 4.1$ \\
\hline 18 & 633 & purE & 72 & & 20 & Phosphoribosylamino subunit & $21 / 4$ & $21.7 / 4.07$ \\
\hline 19 & 1180 & msrA & 71 & & 38 & $\begin{array}{l}\text { Peptide methionine sulfoxide } \\
\text { red. }\end{array}$ & 19.4/4.2 & $21.1 / 4.18$ \\
\hline 20 & 1607 & cheC2 & 76 & & 12 & Chemotaxis protein & $21 / 4.23$ & $21.7 / 4.2$ \\
\hline 21 & 2118 & pyrE2* & 25 & 51 & 22 & Orotatephosphoribosyl transferase & $18 / 4.1 \mid$ & $19.2 / 4.13$ \\
\hline 22 & 626 & maoC2* & 27 & 52 & 22 & Acyl Dehydratase & $16.8 / 4.15$ & $16.9 / 4.2$ \\
\hline 23 & 1807 & vng $/ 807 \mathrm{H}$ & 55 & & 38 & Hypothetical & $15 / 4.29$ & $16 / 4.32$ \\
\hline 24 & 6254 & vng6254* & 21 & 42 & 12 & Conserved Hypothetical & | I. $4 / 3.85$ & $12.2 / 3.9$ \\
\hline 25 & 1137 & $r p / l 8 E^{*}$ & 22 & 44 & 17 & Ribosome assembly & $12.5 / 5.6$ & $12.1 / 5.62$ \\
\hline 26 & 1157 & rphs6* & 30 & 47 & 12 & Ribosome assembly & $12.7 / 3.79$ & $|2.5 / 3.8|$ \\
\hline 27 & 2467 & $r p / 3 I E$ & 110 & & 71 & Ribosome assembly & $10 / 4.52$ & $10.2 / 4.4$ \\
\hline 28 & 1922 & $\operatorname{trh} 5^{*}$ & 32 & 54 & 26 & Lrp like regulator & $8.0 / 4.24$ & $8.4 / 4.11$ \\
\hline 29 & 1300 & vng $/ 300 \mathrm{H}^{*}$ & 49 & 71 & 91 & Hypothetical & $6.5 / 3.91$ & $8.0 / 4.0$ \\
\hline 30 & 2047 & $r p s 27 a E^{*}$ & 30 & 49 & 10 & Ribosome assembly & $6 / 3.87$ & $8.2 / 3.86$ \\
\hline
\end{tabular}

*Proteins identified by MALDI-TOF 
46 proteins was abruptly decreased as compared to control cells growing at $42^{\circ} \mathrm{C}$. Based on accurate comparison of representative gels from control, and heat treated samples, it was observed that predicted, and experimental molecular weights, and pIs values of Hsps were closely matched. In the present investigation the precise identification was based on available genomic information, bioinformatic analysis, in combination with experimental data.

The results clearly indicate that when the growing cells are shifted to elevated temperature, there is enhanced synthesis of five heat shock proteins. Among them, three belong to the category of small heat shock proteins (sHsp) and two to the DnaJ family, respectively. Thus, based on bioinformatic analysis and differential proteomic approaches we were able to identify putative molecular chaperones like DnaJ, GrpE, and three small heat shock proteins sHsp-1, Hsp-5, and sHsp-2 in heat shocked cells (Fig. 3A $\& \mathrm{~B} ;$ Table 2). In each case, the experimental $\mathrm{M}_{\mathrm{r}}$ and $\mathrm{pI}$ values of these putative identified heat shock proteins were close to theoretical values of genomic data. These findings corroborate earlier reports that small heat shock proteins (sHsps) are upregulated significantly under conditions of cellular stress like heat shock [44,45]. Most archaeal genomes contain one or two small heat shock genes, however, in Halobacterium NRC-1 genome, there are three copies of $s H s p$ [19], which are functional, and their synthesis is up-regulated upon heat stress. However, these proteins have chaperonin properties and are also expressed at basal levels under optimal growth temperatures like the sHsps of other organisms. Thus, it seems likely that sHsps play indispensable roles in the molecular chaperone system of Halobacterium NRC-1, and help organism survive under extreme stress conditions. The results indicate that sHsp, DnaJ and GrpE are part of chaperone network which help in refolding of denatured proteins and help normal proteins maintain their native folding state under severe stress [46]. Interestingly, although more than $40 \%$ of all heat shock proteins present in the genome were identified, other expected heat shock proteins, DnaK, Lon, HtrA, and HtpX could not be identified, possibly reflecting the limitation of this approach.
Quantitative analysis of the five putative identified heat shock proteins clearly showed that the three small heat shock proteins sHsp-1, Hsp-5 and sHsp-2 are more than 2-fold induced under heat shock conditions as compared to control (Fig. 4). These three small heat shock proteins predicted in Halobacterium genome share 35\% sequence similarity and belong to Hsp20/alpha crystallin family (PF00011), which is involved in the development of thermotolerance in other systems [47]. Earlier reports have suggested that $16.5 \mathrm{kDa}$ small heat shock proteins from $M$. jannaschii suppress the aggregation of normal proteins

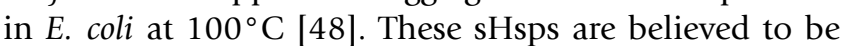
ATP-independent chaperones that prevent aggregation, and are important in refolding of denatured proteins in combination with other Hsps in the cell. It is also believed that sHsps bind to denatured proteins accumulated under stress conditions, and maintain them in a folding-competent state [49].

There was also more than a 2-fold induction of DnaJ and GrpE in heat shocked cells of Halobacterium NRC-1 as compared to control (Fig. 4). Interestingly, in Halobacterium NRC-1, DnaJ and GrpE chaperones of bacterial type which form cellular chaperone machinery capable of repairing heat induced protein damage in growing cell $[50,51]$.

\section{Conclusion}

The present report has attempted to optimize conditions to resolve the acidic proteome of Halobacterium NRC-1. Acidic proteins tend to precipitate in acidic range and this phenomenon results in poor focusing. Using the modified protocol suggested, it is possible to minimize both vertical and horizontal streaking, allowing proteins to focus in the acidic range. The combination of 2-D gel analysis, LC-MS/MS and MALDI-TOF has enabled the identification of several stress proteins, proteins important for DNA replication and repair, translation regulation, transport, chemotaxis, and housekeeping. For the first time it has been clearly established that Halobacterium NRC-1 develop thermotolerance at elevated temperatures through expression of several stress proteins. Furthermore, that expression of stress proteins at under sublethal conditions affords protection from much more severe stresses. By employing differential proteomic approach,

Table 2: Bioinformatic analysis of heat shock proteins, identified on 2-DE from thecells grown at normal $\left(42^{\circ} \mathrm{C}\right)$, and elevated temperatures $\left(49^{\circ} \mathrm{C}\right)$.

\begin{tabular}{lllll}
\hline HSP name & Predicted MW & Predicted pl & Calculated MW & Calculated pl \\
\hline DnaJ & 41.71 & 4.36 & 41.8 & 4.35 \\
GrpE & 23.86 & 3.95 & 24.1 & 3.88 \\
sHsp-I & 14.15 & 4.12 & 14.15 & 4.15 \\
sHsp-2 & 18.53 & 4.07 & 18.3 & 4.04 \\
Hsp-5 & 14.3 & 4.25 & 14.5 & 4.30 \\
\hline
\end{tabular}




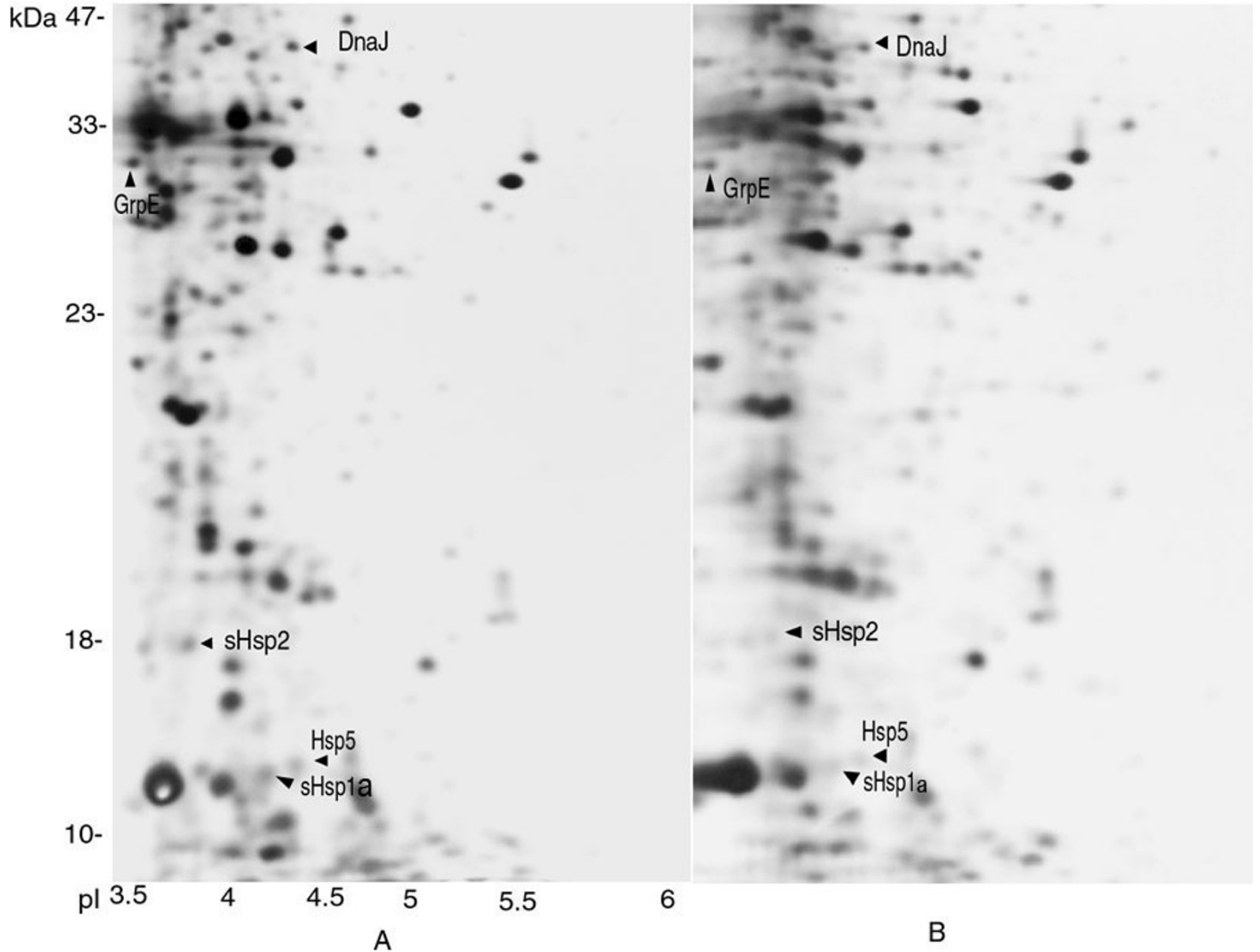

\section{Figure 3}

Comparative analysis of 2-D gels from heat shocked $\left(49^{\circ} \mathrm{C}\right)$, and Control $\left(42^{\circ} \mathrm{C}\right)$ cells. A: Cells shifted and grown at elevated temperature $\left(49^{\circ} \mathrm{C}\right)$; B: Cells grown at normal growth temperature $\left(42^{\circ} \mathrm{C}\right)$.

five heat shock proteins were identified which were up regulated under temperature stress in Halobacterium NRC1 , and allow cells to survive under severe stress.

\section{Methods}

Preparation of the cell lysate

For protein extraction and cell lysate preparation, Halobacterium NRC-1 (ATCC 700922) was grown in batch cultures in $\mathrm{CM}^{+}$medium with shaking in light. When cultures reached $0.9 \mathrm{OD}_{600}$ the growing cultures were divided and pairs grown in either standard conditions $\left(42^{\circ} \mathrm{C}\right)$, or with heat shock $\left(49^{\circ} \mathrm{C}, 8\right.$ hours). Triplicate cultures were harvested and cell lysates were prepared. Briefly, cells from 25 $\mathrm{ml}$ of culture were collected by centrifugation at 10,000 $\times$ $\mathrm{g}$ for $10 \mathrm{~min}$. The cell pellet was resuspended in $2.5 \mathrm{ml}$ of resuspension buffer ( 5 mM Tris-HCl, pH 8.0, 2 \% Tween20, and $1 \mathrm{mM}$ PMSF, (freshly prepared). The homoge- nized cell suspension was disrupted using a French Press with three passages at 16000 psi. Unbroken cells and debris were removed by centrifugation at $8000 \times \mathrm{g}$ for 10 $\min$ at $4{ }^{\circ} \mathrm{C}$, and the supernatant containing the soluble fraction of proteins was transferred into a separate tube. Subsequently, the lysate was digested with $100 \mu \mathrm{g} / \mathrm{ml}$ DNase, and $40 \mu \mathrm{g} / \mathrm{ml} \mathrm{RNase,} \mathrm{for} 60 \mathrm{~min}$ at $37^{\circ} \mathrm{C}$ to remove nucleic acids. After rapid cooling to $4{ }^{\circ} \mathrm{C}$, the soluble fraction was dialyzed using a $3000 \mathrm{Da}$ cutoff dialysis bag against $5 \mathrm{mM}$ Tris- $\mathrm{HCl} \mathrm{pH} 8.0$ for 24 hours at $4{ }^{\circ} \mathrm{C}$ with at least four changes. Protein concentrations were determined by use of a Bradford dye-based protein assay reagent from Bio-Rad.

\section{2-D gel electrophoresis}

For 2-DE analysis, $80 \mu \mathrm{g}$ of dialysed protein extract was mixed with $250 \mu \mathrm{l}$ of rehydration buffer (8.5 M urea, $2 \%$ 


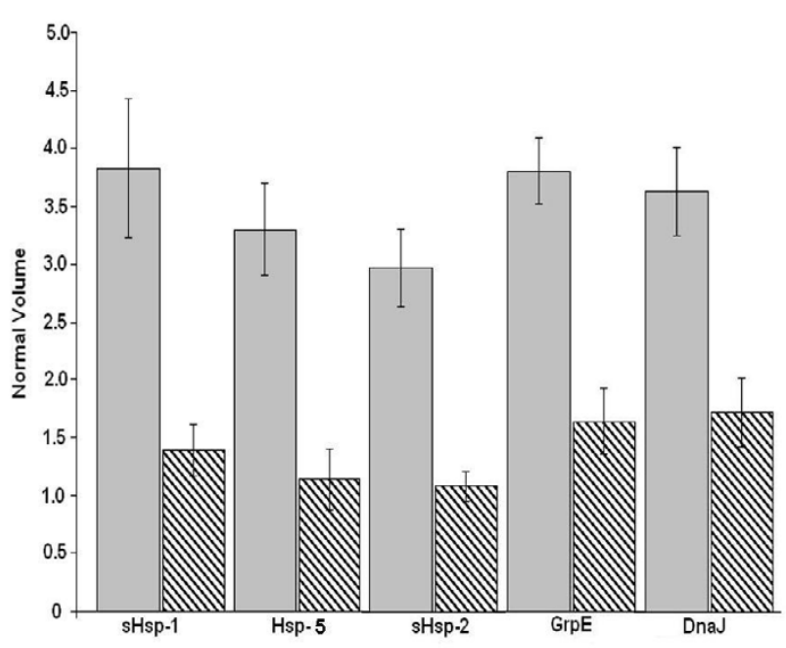

Figure 4

Quantative analysis of heat shock proteins differentially expressed at $42{ }^{\circ} \mathrm{C}$ (patterned columns), and $49^{\circ} \mathrm{C}$ (shaded columns).

TWEEN 20, 2 \% CHAPS, $0.5 \%$ IPG buffer, pH 3-10, 20 $\mathrm{mM}$ DTT and $0.002 \%$ bromophenol blue). After thorough (10 min, $2 \mathrm{~min}$ interval) vortexing, the protein sample was centrifuged at $10,000 \times \mathrm{g}$ for $5 \mathrm{~min}$. The cleared protein sample was pipetted into IPG strip holders (IPGphor, Pharmacia Biotech) and incubated with $11 \mathrm{~cm}$ IPG ready strips, of the $\mathrm{pH}$ range $3-6$. The IPG strips were allowed to rehydrate for $16 \mathrm{~h}$ at $50 \mathrm{~V}$ at $22^{\circ} \mathrm{C}$, which enhanced resolution of proteins on the gel. IEF was performed at $500 \mathrm{~V}$ for $1 \mathrm{~h}, 1000 \mathrm{~V}$ for $1 \mathrm{~h}$ and $8000 \mathrm{~V}$ for 2 $\mathrm{h}$ for a total of $24000 \mathrm{Vh}$. After IEF, IPG strips were equilibrated (15 min) in $10 \mathrm{ml}$ Equilibration buffer $(50 \mathrm{mM}$ Tris-Cl, pH 8.8, $6 \mathrm{M}$ urea, $30 \%$ glycerol, $2 \%$ SDS, $20 \mathrm{mM}$ DTT and $0.002 \%$ bromophenol blue) followed by reequilibration (15 $\mathrm{min}$ ) in the same buffer but containing $20 \mathrm{mM}$ iodoacetamide to minimize the streaking during second dimension electrophoresis. After equilibration, the IPG strip were placed onto a $12.5 \%$ SDS-PAGE gel ( 18 $\times 24 \mathrm{~cm}$ ). The strips were sealed with the help of $0.5 \%$ agarose in electrophoresis buffer. Proteins were electrophoresed at $120 \mathrm{~V}$ for $12 \mathrm{~h}$ using a Hoefer SE 600 electrophoresis unit. Following electrophoresis, gels were silver stained according to Blum et al [52] and stored in $10 \%$ acetic acid at $4^{\circ} \mathrm{C}$.

\section{Image analyses of 2-D gels}

The silver stained gels were scanned using a Kodak EDAS 290 imaging system. Image analysis was performed using the ImageMaster 2D Elite software (Pharmacia Biotech), as described by Krapfenbauer et al 2001 [23]. After spot detection and background subtraction (non spot mode), rigorous editing (automatic and manual), and filtering was performed. Subsequently, gel images were overlaid, and matched, and the quantitative determination of a spots volume was performed (mode: total spot volume normalization). For each analysis, statistical data (from triplicate gels of two independent protein extractions) showed a high level of reproducibility between normalized spot volumes. Normalized volumes of spots from control and experimental gels were exported into Excel (Microsoft) for the calculation of the levels of differential expression.

\section{Trypsin digestion and gel extraction of peptides}

Samples were resolved through 2-D gel electrophoresis using IPG ready strip pH 3-6. Proteins spots were excised from silver stained gels and washed with milli-Q water and twice with $50 \%$ acetonitrile for $15 \mathrm{~min}$. Gel pieces were then washed with a $1: 1$ solution of $0.1 \mathrm{M} \mathrm{NH}_{4} \mathrm{HCO}_{3}$ and acetonitrile for $15 \mathrm{~min}$. For destaining, gel pieces were incubated in $10 \mathrm{mM}$ DTT/0.1 $\mathrm{M} \mathrm{NH}_{4} \mathrm{HCO}_{3}$ for $45 \mathrm{~min}$ at $56^{\circ} \mathrm{C}$ to reduce the protein, followed by incubation in 55 $\mathrm{mM}$ iodoacetamide/0.1 $\mathrm{M} \mathrm{NH}_{4} \mathrm{HCO}_{3}$ for $30 \mathrm{~min}$ at room temperature in the dark for alkylation. Supernatants were discarded and gel pieces were washed with $100 \mu \mathrm{l}$ $\mathrm{NH}_{4} \mathrm{HCO}_{3}$, followed by two washes ( 5 min each with vortexing and brief centrifugation) with $100 \mu \mathrm{l}$ (or enough to cover) of $25 \mathrm{mM} \mathrm{NH}_{4} \mathrm{HCO}_{3}$ in $50 \%$ acetonitrile. The gel particles were dehydrated in a Speed Vac (Thermo Savant) to complete dryness and rehydrated with trypsin digestion buffer $\left(50 \mathrm{mM} \mathrm{NH} \mathrm{HCO}_{3}, 5 \mathrm{mM} \mathrm{CaCl}_{2}\right.$ ). For trypsin digestion $12.5 \mathrm{ng} / \mu \mathrm{l}$ of porcine trypsin (Promega, Madison, USA) was added in a final volume of $25 \mu \mathrm{l}$. Tubes were incubated on ice for $45 \mathrm{~min}$, after which $25 \mathrm{mM}$ $\mathrm{NH}_{4} \mathrm{HCO}_{3}$ was added and tubes were further incubated overnight at $37^{\circ} \mathrm{C}$. The supernatant was removed into a clean siliconized tube and extracted twice in $50 \%$ acetonitrile and $5 \%$ formic acid and acetonitrile. The mixture was vortexed $20-30 \mathrm{~min}$ and centrifuged. Supernatant was pooled into a separate tube and the volume was reduced to $10 \mu \mathrm{L}$ using a Speed Vac. Subsequently, the digested mixture was passed through a C18 ZipTip (Millipore). Peptides were eluted into a siliconized tube with 3 $\mu \mathrm{l}$ of $5 \%$ formic acid prior to analysis by MALDI.

\section{Protein identification by LC-MSIMS and MALDI-TOF}

LC-MS/MS analysis was performed by injecting $10 \mu \mathrm{l} \mathrm{sam-}$ ple into the Surveyor HPLC system fitted with BioBasic C18 packed nanospray tip (New Objective, Woburn, MA) directly coupled to a LCQ Deca XP plus ion-trap mass spectrometer equipped with a nano-LC electrospray ionization source (Thermo Finnigan, San Jose, CA). The spray voltage was $1.70 \mathrm{kV}$, the capillary temperature was $150^{\circ} \mathrm{C}$, and ion-trap collision fragmentation spectra were obtained by collision energies of 35 units. Each full mass 
spectrum was followed by three MS/MS spectra of the three most intense peaks. The Dynamic Exclusion was enabled. After each sample, an injection of $10 \mu \mathrm{l}$ of $0.1 \%$ aqueous formic acid was analyzed to ensure proper equilibration of the system.

The 15 raw files were searched against the NCBInr database using SEQUEST (ThermoFinnigan, San Jose, CA), which correlates the experimental tandem mass spectra against theoretical tandem mass spectra from amino acid sequences obtained from the National Center for Biotechnology Information (NCBI) sequence database. Tryptic cleavages at only Lys or Arg and up to two missed internal cleavage sites in a peptide were allowed. The maximal allowed uncertainty in the precursor ion mass was $\mathrm{m} / \mathrm{z}$ 1.4. Mass spectra were acquired by data-dependent ion selection from a full range as well as discrete and narrow survey scan $\mathrm{m} / \mathrm{z}$ ranges to increase the number of identifications

The output files were filtered by Xcorr filter (Xcorr+Del$\operatorname{taCn})$. The value of XCorr and DeltaCn were Xcorr $>2.0$ for +2 charged peptides, with partially and fully tryptic ends and DeltaCn $>0.1$.

MALDI-TOF analysis was performed by reconstituting the dried peptides in $10 \mu \mathrm{l}$ of $0.1 \%$ TFA and desalted using the C18 ZipTip column from Millipore (Bedford, MA). One $\mu \mathrm{L}$ of concentrated sample was spotted onto the MALDI target plate with $1 \mu \mathrm{l}$ of $5 \mathrm{mg} / \mathrm{ml} \alpha$-cyano- 4 hydroxycinnamic acid in a 1:1 v:v mixture of $50 \%$ acetonitrile/0.05\% TFA. The sample was allowed to dry for approximately 15-20 min before placing the sample plate to the mass spectrometer for MALDI-MS analysis. The data were collected using the Kratos AXIMA CFR MALDI-TOF (Shimadzu Biotech, USA) in the linear mode. The spectra were internally calibrated using known trypsin autolysis peaks.

The monoisotopic peptide mass fingerprinting data obtained from MALDI-TOF were used to search nonredundant databases [53], using the MASCOT search engine with varying parameter settings [54] (peptide mass tolerance from 0.5 to $1 \mathrm{Da}$, missed cleavages up to 2). External calibration was performed using Calibration Mixture 2 from the Sequazyme and Peptide Mass Standards Kit (Applied Biosystems, Foster City, CA).

\section{Abbreviation}

2D - two-dimensional gel electrophoresis.

IEF - isoelectric focusing.

PAGE - polyacrylamide gel electrophoresis.
LC-MS/MS - liquid chromatography coupled tandem mass spectrometry.

MALDI-TOF - Matrix assisted laser desorption ionizationtime of flight.

HSP - Heat shock proteins.

sHsp - small Heat shock proteins.

\section{Competing interests}

The author(s) declare that they have no competing interests.

\section{Acknowledgements}

This work was supported from the grant by National Science Foundation. Author thanks Dr Peter L. Gutierrez and Shabina Ali-Khan, Proteomic Core facility, University of Maryland, Medical Center, and John Hopkins University School of Medicine for their kind help. I also thank Dr B. Joshi for critically reading the manuscript.

\section{References}

I. McCready S, Marcello L: Repair of UV damage in Halobacterium salinarum. Biochem Soc Trans 2003, 31 1:694-698.

2. Kennedy SP, Ng WV, Salzberg SL, Hood L, DasSarma S: Understanding the adaptation of Halobacterium species NRC-I to its extreme environment through computational analysis of its genome sequence. Genome Research 200I, II:164I-I650.

3. Reindel S, Schmidt CL, Anemuller S, Matzanke BF: Expression and Regulation Pattern of Ferritin-like DpsA in the Archaeon Halobacterium Salinarum. Biometals 2006, 19:19-29.

4. Ng WV, Kennedy SP, Mahairas GG, Berquist B, Pan M, Shukla HD, Lasky SR, Baliga NS, Thorsson V, Sbrogna J, Swartzell S, Weir D, Hall J, Dahl TA, Welti R, Goo YA, Leithauser B, Keller K, Cruz R, Danson MJ, Hough DW, Maddocks DG, Jablonski PE, Krebs MP, Angevine CM, Dale H, Isenbarger TA, Peck RF, Pohlschroder M, Spudich JL, Jung KW, Alam M, Freitas T, Hou S, Daniels CJ, Dennis PP, Omer AD, Ebhardt H, Lowe TM, Liang P, Riley M, Hood L, DasSarma S: Genome sequence of Halobacterium species NRC-I. PNAS USA 2000, 97:|2176-12181.

5. DasSarma S, Robb FT, Place AR, Sowers KR, Schreier HJ, Fleischmann EM: Archaea: a laboratory manual - halophiles. Cold Spring Harbor Laboratory Press; 1995.

6. Evans EC, Horn T, Wagner MA, Eschenbrenner M, Mujer CV, DelVecchio VG: Isolation protocol for two-dimensional-polyacrylamide gel electrophoresis analysis of Haloferax volcanii proteome. Biotechniques 2003, 3:478-482.

7. Cho CW, Lee SH, Choi J, Park SJ, Ha DJ, Kim HJ, Kim CW: Improvement of the two-dimensional gel electrophoresis analysis for the proteome study of Halobacterium salinarum. Proteomics 2003, I 2:2325-2329.

8. Goo YA, Yi EC, Baliga NS, Tao WA, Pan M, Aebersold R, Goodlett DR, Hood L, Ng WV: Proteomic Analysis of an Extreme Halophilic Archaeon Halobacterium sp. NRC-I. Mol Cell Proteomics 2003, 2(8):506-524.

9. Blonder J, Conrads TP, Yu LR, Terunuma A, Janini GM, Issaq HJ, Vogel JC, Veenstra TD: A detergent- and cyanogen bromide-free method for integral membrane proteomics: application to Halobacterium purple membranes and the human epidermal membrane proteome. Proteomics 2004, 4(I):31-45.

10. Wilkins MR, Gasteiger E, Sanchez JC, Bairoch A, Hochstrasser DF: Two-dimensional gel electrophoresis for proteome projects: the effects of protein hydrophobicity and copy number. Electrophoresis 1998, 19(8-9): I50|-5.

II. Sinha PK, Kottgen E, Stoffler-Meilicke M, Gianazza E, Righetti PG: Two-dimensional maps in very acidic immobilized $\mathrm{pH}$ gradients. J Biochem Biophys Methods 1990, 20(4):345-52. 
12. Klein C, Garcia-Rizo C, Bisle B, Scheffer B, Zischka H, Pfeiffer F, Siedler F, Oesterhelt D: The membrane proteome of Halobacterium salinarum. Proteomics 2005, 5(I): 180-197.

13. Morimoto RI, Santoro MG: Stress-inducible responses and heat shock proteins: new pharmacologic targets for cytoprotection. Nature Biotechnol 1998, I 6(9):833-8.

14. Baliga NS, Bjork SJ, Bonneau R, Pan M, Iloanusi C, Kottemann MC, Hood L, DiRuggiero J: Systems level insights into the stress response to UV radiation in the halophilic archaeon Halobacterium NRC-I. Genome Res 2004, I 4: I025- 035.

15. Hartl FU: Protein folding. Secrets of a double-doughnut. Nature 1994, 37 I:557-9.

16. Shukla HD, Singh BR: Identification of DnaJ-like chaperone in Clostridium botulinum type A. J Protein Chem 1999, I 8(6):695-700.

17. Trent JD, Kagawa HK, Yaoi T, Olle E, Zaluzec NJ: Chaperonin filaments: the archaeal cytoskeleton? Proc Natl Acad Sci U S A 1997, 94( I 0):5383-8.

18. Buchner J: Supervising the fold: functional principles of molecular chaperones. FASEB J 1996, I0(I): 10-19.

19. Narberhaus F: Aplha-Crystallin-Type Heat Shock Proteins: Socializing Minichaperones in the Context of a Multichaperone Network. MMBR 2002, 66:64-93.

20. Eisenberg H: Life in unusual environments: Progress in understanding the structure and function of enzymes from extreme halophilic bacteria. Arch Biochem Biophys I 995, 3 I 8: I -5.

21. Park SJ, Joo WA, Choi J, Lee SH, Kim CW: Identification and characterization of inosine monophosphate dehydrogenase from Halobacterium salinarum. Proteomics 2004, 4(I I ):3632-4I.

22. Lee MS, Joo WA, Kim CW: Identification of a novel protein D3UPCA from Halobacterium salinarum and prediction of its function. Proteomics 2004, 4(I I ):3622-3I.

23. Krapfenbauer K, Berger M, Friedlein A, Lubec G, Fountoulakis $M$ : Changes in the levels of low-abundance brain proteins induced by kainic acid. Eur J Biochem 200I, 268:3532-3537.

24. Link AJ, Robison K, Church GM: Comparing the predicted and observed properties of proteins encoded in the genome of Escherichia coli K-I2. Electrophoresis 1997, I 8(8): I 259-3। 3.

25. Jaffe JD, Berg HC, Church GM: Proteogenomic mapping as a complementary method to perform genome annotation. Proteomics 2004, 4(I):59-77.

26. Tebbe A, Klein C, Bisle B, Siedler F, Scheffer B, Garcia-Rizo C, Wolfertz J, Hickmann V, Pfeiffer F, Oesterhelt D: Analysis of the cytosolic proteome of Halobacterium salinarum and its implication for genome annotation. Proteomics 2005, 5(I): I68-79.

27. Klunker D, Haas B, Hirtreiter A, Figueiredo L, Naylor DJ, Pfeifer G, Muller V, Deppenmeier U, Gottschalk G, Hartl FU, Hayer-Hartl M: Coexistence of group I and group II chaperonins in the archaeon Methanosarcina mazei. I Biol Chem 2003, 278:33256-332667.

28. Karlin S, Mrazek J, Ma J, Brocchieri L: Predicted highly expressed genes in archaeal genomes. Proc Natl Acad Sci U S A 2005, 102:7303-7308.

29. Trent JD, Kagawa HK, Yaoi T, Olle E, Zaluzec NJ: Chaperonin filaments: the archaeal cytoskeleton? Proc Natl Acad Sci U S A 1997, 94(I 0):5383-8.

30. Rizzitello AE, Harper JR, Silhavy TJ: Genetic Evidence for Parallel Pathways of Chaperone Activity in the Periplasm of Escherichia coli. I Bacteriol 200 I, I 83:6794-6800.

31. Ezraty B, Grimaud R, El Hassouni M, Moinier D, Barras F: Methionine sulfoxide reductases protect $F$ from oxidative damages in Escherichia coli. EMBO J 2004, 23: I868-I877.

32. Moskovitz J, Rahman MA, Strassman J, Yancey SO, Kushner SR, Brot N, Weissbach H: Escherichia coli Peptide Methionine Sulfoxide Reductase Gene: Regulation of Expression and Role in Protecting Against Oxidative Damage. J of Bacteriology 1995, 1 77:502-507.

33. Pena MM, Bullerjahn GS: The DpsA protein of Synechococcus sp. Strain PCC7942 is a DNA-binding hemoprotein. Linkage of the Dps and bacterioferritin protein families. J Biol Chem 1995 , 270(38):22478-82.

34. Nair S, Finkel SE: DpsA protects cells against multiple stresses during stationary phase. J of Bacteriology 2004, I 86:4192-4198.

35. Neuwald AF, Aravind L, John, Spouge L, Koonin EV: AAA+: A Class of Chaperone-Like ATPases Associated with the Assembly,
Operation, and Disassembly of Protein Complexes. Genome Research 1999, 9:27-43.

36. Sancar A: DNA Excision repair. Annu Rev Biochem 1996, 65:43-8I.

37. Locher KP, Lee AT, Rees DC: The E. coli BtuCD structure: a framework for $A B C$ transporter architecture and mechanism. Science 2002, 296: $1091-1098$

38. Rudolph J, Nordmann B, Storch KF, Gruenberg H, Rodewald K, Oesterhelt D: A family of halobacterial transducer proteins. FEMS Microbiol Lett 1996, 139:161-168.

39. Tittor J, Paula S, Subramaniam S, Heberle J, Henderson R, Oesterhelt $D$ : Proton translocation by bacteriorhodopsin in the absence of substantial conformational changes. I Mol Biol 2002 , 319:555-565.

40. Bernhardt J, Volker U, Volker A, Antelmann H, Schmid R, Mach H, Hecker M: Specific and general stress proteins in Bacillus subtilis - a two-deimensional protein electrophoresis study. Microbiology 1997, 143:999-1017.

4I. Peeples TL, Kelly RM: Bioenergetic response of the extreme thermoacidophile Metallosphaera sedula to thermal and nutritional stress. Appl Environ Microbiol I995, 6 I:23 I4-232 I.

42. Usui K, Ishii N, Kawarabayasi AY, Yohda M: Expression and biochemical characterization of two small heat shock proteins from the thermoacidophilic crenarchaeon Sulfolobus tokodaii strain 7. Protein Science 2004, I 3:|34-| 44.

43. Kim R, Kim KK, Yokota H, Kim SH: Small heat shock protein of Methanococcus jannaschii, a hyperthermophile. Proc Natl Acad Sci U S A 1998, 95( 16):9129-33.

44. Roy SK, Nakamoto $\mathrm{H}$ : Cloning, characterization, and transcriptional analysis of a gene encoding an alpha-crystallin-related, small heat shock protein from the thermophilic cyanobacterium Synechococcus vulcanus. J of Bacteriol 1998, I 80:3997-400 I

45. Laksanalamai P, Maeder DL, Robb FT: Regulation and Mechanism of Action of the Small Heat Shock Protein from the Hyperthermophilic Archaeon Pyrococcus furiosus. I of Bacteriology 2001, I 83:5198-5202.

46. Ellis RJ, Hartl FU: Principles of protein folding in the cellular environment. Curr Opin Struct Biol 1999, 9:102-II0.

47. van den IJssel PR, Overkamp P, Knauf U, Gaestel M, de Jong WW: Alpha -crystallin confers cellular thermoresistance. FEBS Lett 1994, 355(I):54-56.

48. Kim R, Lai L, Lee HH, Cheong GW, Kim KK, Wu Z, Yokota H, Marqusee $\mathrm{S}$, Kim $\mathrm{SH}$ : On the mechanism of chaperone activity of the small heat-shock protein of Methanococcus jannaschii. Proc Natl Acad Sci U S A 2003, I 00( I 4):8I 5 I-5

49. Lee G], Roseman AM, Saibil HR, Vierling E: A small heat shock protein stably binds heat denatured model substrates and can maintain a substrate in a folding competent state. EMBO |997, 16:659-67|.

50. Schroder H, Langer T, Hartl FU, Bukau B: DnaK, DnaJ and GrpE form a cellular chaperone machinery capable of repairing heat-induced protein damage. EMBO $]$ I I:4 | 37-44.

5I. Mujacic M, Bader MW, Baneyx F: Escherichia coli Hsp3 I functions as a holding chaperone that cooperates with the DnaK-DnaJGrpE system in the management of protein misfolding under severe stress conditions. Mol Microbiol 2004 , 5 I (3):849-59.

52. Blum H, Beier H, Gross HJ: Improved silver staining of plant proteins, RNA and DNA in polyacrylamide gels. Electrophoresis 1987, 8:93-99.

53. [http://www.expasy.org/].

54. [http://www.matrixscience.com] 